\title{
RESEARCHPAPER
}

\section{Bio-efficacy of insecticides against aphid (Aphis craccivora Koch) infesting cowpea [Vigna ungiculata (L.) Walp.]}

\author{
B. SWARNALATA, S.M. PATEL, H.V. PANDYA AND S.D. PATEL \\ Department of Entomology, ASPEE College of Horticulture and Forestry, Navsari Agricultural University, NAVSARI \\ (GUJARAT) INDIA \\ Email : hvpandya@nau.in
}

Article Info : Received : 08.12.2014; Revised : 04.03.2015; Accepted : 18.03.2015

Eleven different insecticides were evaluated for their efficacy against A. craccivora at Regional Horticulture Research Station, ASPEE College of Horticulture and Forestry, Navsari Agricultural University, Navsari, Gujarat during Rabi season of the year 2013-2014. The treatment imidacloprid 0.005 per cent ( 0.19 aphid index/plant) was found to be most effective followed by thiamethoxam 0.01 per cent ( 0.33 aphid index/plant). Verticillium lecanii 0.40 per cent $(0.58$ aphid index/plant), azadirachtin 0.002 per cent $(0.62$ aphid index/plant) and dimethoate 0.03 per cent $(0.77$ aphid index/plant) were the next in order. The highest marketable pod yield $(30.37 \mathrm{q} / \mathrm{ha})$ and maximum per cent increase in pod yield of cowpea over control $(84.28 \%)$ was recorded from the plots treated with thiamethoxam 25 WG @ 0.01 per cent.

Key words : Bio-efficacy, Imidacloprid, Cowpea, Aphids

How to cite this paper : Swarnalata, B., Patel, S.M., Pandya, H.V. and Patel, S.D. (2015). Bio-efficacy of insecticides against aphid (Aphis craccivora Koch) infesting cowpea [Vigna ungiculata (L.) Walp.]. Asian J. Bio. Sci., 10 (1) : 83-88. 